\title{
Transparency and Accountability in Public Financial Management: A Stewardship Account at Kano State Ministry of Finance, Nigeria
}

\author{
Kabiru Isa Dandago ${ }^{1 \& 2}$ \\ ${ }^{1}$ Out-going Commissioner of Finance, Kano, Nigeria \\ ${ }^{2}$ Department of Accounting, Bayero University, Kano, Nigeria \\ Correspondence: Prof. Kabiru Isa Dandago PhD, FCA, FCTI, FNIM, FITM, MNES, AAIF, Department of \\ Accounting, Bayero University, Kano, Nigeria. Tel: 23-480-2336-0386.
}

Received: January 4, 2018

Accepted: February 27, 2018

Online Published: March 5, 2018

doi:10.5430/ijfr.v9n2p76

URL: https://doi.org/10.5430/ijfr.v9n2p76

\begin{abstract}
This paper aims at accounting for the transparency and accountability demonstrated through the unity and togetherness of the functionaries of the Ministry of Finance Kano State, Nigeria as they collectively discharge the five key responsibilities of the Ministry during a period of 28 months (June 2015 to October 2017) under the humble leadership of the author. The paper is skewed towards practical (as against theoretical) dispensation of effective public finance management at the sub-national level in Nigeria, covering revenue management, expenditure management, debt management, investment management and wealth creation and management. This exposure of transparency and accountability has attracted some encouraging comments from hundreds of concerned analysists and lovers of transparency and accountability from different parts of the world, out of which a select sampled comments have been captured in the paper. The paper also attempts some responses to the seven questions raised by one of the commentators (An International Public Financial Management Expert) in respect of the earlier internet posting made on the subject matter. The paper recommends that research students, scholars and practitioners should conduct further studies on the issues raised in the paper so as to find solutions to the weak nature of the practice of prudence, transparency and accountability in the public sector of developing economies, like Nigeria.
\end{abstract}

Keywords: transparency, accountability, stewardship, public finance management, ministry, leadership

\section{Introduction}

It is with high gratitude to Allah that this submission on account of the stewardship of the Ministry of Finance, Kano State, Nigeria during a period of 28 months is made, containing all the issues that should be noted by all public finance managers at the sub-national and national levels, in particular, and all other public interest servants in the developing economies and beyond. The account of stewardship is aimed at promoting the principles of Transparency and Accountability in Public Finance Management and also in ensuring that ethical behaviors are assured in managing public offices, especially issues that are financial management related.

The journey to this stewardship process started on $22^{\text {nd }}$ June, 2015, following the swearing-in of the author on Saturday $20^{\text {th }}$ June, 2015 as the newly appointed Commissioner of Finance by His Excellency, the Governor of Kano State, Dr. Abdullahi Umar Ganduje OFR. In taking the oath of office, the author was made to carry the full text of the Holy Qur'an on his humble shoulder, telling thousands eye-witnesses that the duties assigned would be discharged without fear or favour and that the provisions of the Constitution of the Federal Republic of Nigeria would be upheld with high degree of honesty and integrity.

This statement of stewardship for 28 months tenure-ship highlights the modest achievements recorded by the Ministry of Finance, Kano State, Nigeria during the period, with a view to serving as a guide to the In-coming Commissioner on where the Ministry is and how to make it stronger during the succeeding period. Highlights of the achievements recorded during the 28 months of the united and all-inclusive leadership of the Ministry are captured under the five main functions of the ministry.

The paper is divided into six parts, with Part 1 covered by this introduction. Part 2 highlights 48 achievements recorded by the Ministry of Finance, Kano state, Nigeria during the period under review; Part 3specifically emphasizes on unity and togetherness as the key achievement of the Ministry; Part 4 is about the commentators 
analysis of the achievements recorded; Part 5 carries responses to the seven questions raised by one of the commentators; while Part 6 concludes the paper.

\section{48-Point Achievements on Public Finance Management}

\subsection{Revenue Management}

a) The Ministry led the process of achieving the Internally Generated Revenue (IGR) reform agenda of His Excellency, Dr. Abdullahi Umar Ganduje OFR. This ensures that the Agency responsible for collection of all forms of revenue for the state government (Kano Internal Revenue Service) is professionalized and made autonomous, both administratively and financially.

b) The status of the State was raised from oil-revenue based economy to IGR-based economy, when the state starts enjoying ranking as the best IGR state in the whole of the 19 Northern States, and $5^{\text {th }}$ IGR state in Nigeria.

c) Some relevant revenue generation laws were enacted by the State House of Assembly, with a lot of inputs from the Ministry, all with a view to enhancing the Revenue base of the state government.

d) Efforts have been made to boost the revenue collection process of all the 44 Local Government Councils in the state so that they fall in line with the IGR agenda of the Ganduje's administration. As the Commissioner of Finance, the author had cause to inaugurate a Joint Tax Committee comprising of KIRS, top functionaries of LGCs and representatives of relevant Federal Government Revenue Agencies in the state, all with the aim of boosting the total revenue of both the state government and LGCs, through sources that are of shared mandate.

e) Efforts have been made to ensure that all collectable revenues from the Federal government, and from other sources that have been neglected in the past, are pressurized to ensure that what belongs to the Kano State government in terms of revenue actually comes to it.

f) Revenue from sales of government's scrap assets/materials are kept under the custodianship of the Ministry, as per the handing-over Note developed by the out-going Permanent secretary of the Ministry, Alhaji Muhammad Dankade Ibrahim. In that Handing-Over Note details of the Auctioneers and the scraps sold to them were highlighted and total amount generated given.

g) The Ministry introduced the idea of Single Revenue Account (SRA) and promoted its inclusion in the MDA Revenue Harmonization Law 2016, with a view to ensuring that all revenues belonging to the state government are captured in a single account and reported by the reporting Bank, on monthly basis, before utilization by the State Government.

\subsection{Expenditure Management}

a) Promoting the revival of the Disbursement Committee at the Ministerial level and Cash Management Committee at the Executive level, as per the provision of Financial Regulations. As the two Committees were revived, with the approval of His Excellency, the Governor, the process of executing their duties ensured practical Prudence, Transparency and Accountability in the releases of funds to incur expenditure approved by the State Executive Council or by His Excellency.

b) Ensuring that no funds are released for any project (short term or long term) without approval and authorization, based also on enacted appropriation law of the State House of Assembly.

c) All deductions made for VAT and WHT from companies are remitted to the Federal Inland Revenue Service (FIRS) in good time, so that relevant firms could get the certificates they deserve from the Service.

d) Ensuring that quarterly report on expenditure are made available in good time for quarterly budgetary performance assessment conducted in conjunction with the state Ministry of Planning and Budget.

e) Cleared the backlogs of required answers to audit queries for 2011 to 2013, as required by the Public Accounts Committee (PAC) of the State House of Assembly. The Ministry has also meritoriously answered the few queries submitted by PAC regarding 2014 and 2015 prepared financial statements.

f) The Ministry has respectively promoted the gazette and publication of both the 2014 and 2015 annual financial reports as well as printed the aforementioned two years accounts in separate booklets, meant for distribution to all Accountant General's and commissioners of Finance of the 36 states, related state and Federal Agencies, Federal Capital Territory (FCT) Abuja and other stakeholders. The reports are also to be posted to various websites of the state government. 
g) The audit work on the 2016 Financial Statements (prepared on Accrual IPSAS Basis) is due to have been completed by the end of October 2017, which would ensure publication of the report before the end of the year.

h) Items e, $\mathrm{f}$ and g show that during this 28 months period the Kano State Government is able to be current in its financial reporting, for the first time in the history of the state. This milestone was reached using the expertise, commitment and dedication of relevant staff of the Ministry, without the involvement of any expensive Consultant!

i) Training and re-training of the Final Accounts Staff in the areas of computer based applications, as well as training and re-training of the Final Accounts Staff in the area of applied practical IPSAS accrual basis.

j) Development of SIFMIS in the State, as already preparation has taken place with support from SLOGOR, RTI and ARC to ensure the deployment of SIFMIS Software programme for proper linkage between Ministry of Finance (MOF), Ministry of Budget and Planning (MOB\&P), Office of the Head of Civil Service and Office of the State Auditor General and other Stakeholders.

k) In line with the intent of successful compliance with requirements of migration from Ipsas Cash Basis to Ipsas Acrual Basis, the Ministry of Finance has received an expression of interest from Four (4) reputable consultants on the development and provision of State Assets Register and Valuation of Fixed Assets. The process of selection has already been taken place and the successful firm would be engaged in earnest within the third quarter of year 2017.

\subsection{Debt Management}

a) The Ministry has upgraded the Debt Management Unit with the provision of Computers, Printers, Scanners, Server and Solar Powered Electricity, among others. The Unit is now under Department of Planning, Research and Statistics.

b) The Ministry now proudly responds to requests/queries on Data related to the indebtedness or liabilities of the state government from within and outside the State.

c) The Ministry maintains Timely Submission of Quarterly domestic Debt reports to Debt Management Office, Abuja. The reports for year 2016 and those of Quarters 1, 2 and 3 for 2017 have been submitted to the DMO, Abuja. The reports usually include debt service projection and efforts made at clearing the indebtedness or liabilities of the state government.

d) The Ministry conduct assessment of the State External Loans Profile received from DMO, with critical observations on areas where the state government is shortchanged for appropriate corrective actions to be taken in favour of the state government.

e) The Ministry conducted debt sustainability analysis on the "Budget Support Facility", as per the requirements of the Fiscal Sustainability Plan. The analysis shows that the state government is very lean in terms of indebtedness, which suggests that its debt profile is not any near the optimum level.

f) The Ministry satisfactorily conducted analysis of Intervention Funds (Salary Bailout, MSMEs Loan scheme, CACs, Power Intervention Loan and Infrastructure loan) for the year 2016 and for the first two quarters of 2017.

g) The Ministry is of the view that Bond Issuance (Conventional or Islamic) would be a veritable way of capital mobilization for the execution of various developmental project, as subscribers would readily key-in since the state government is not seriously indebted.

h) For the DMU of the Department of PRS \& DM to continue to function effectively, the Ministry has started addressing the need for the Unit to be provided with: i) Good/suitable furniture as the existing ones are dilapidated and inadequate; ii) New Air-condition system as the ones in use have broken down; iii) Curtains as the ones available are in a very poor state; iv) Recreational facilities as none is available; and v) Laptop computers as none is presently available.

i) The Ministry has also started addressing the need for training on Debt Management issues for PRS\&DM staff; and Installation of the Commonwealth Secretariat Debt Recording Management System (CS-DRMS) Software, with the aid of the West African Institute of Financial and Economic Management (WAIFEM).

\subsection{Investment Management}

a) Through the activities of its Investment wing (Kano State Investment and Property (KSIP Limited), the Ministry has taken measures to mobilize the good people of Kano State to be visibly present in the Nigerian Capital Market and beyond. This was done through the avenue of sensitization seminar organized for all prospective capital market investors at Daula Hotel Kano in 2016. 
b) Arrangement has been concluded to embark on a more aggressive sensitization campaign on the same mission beginning from November 2017 across the three Senatorial Districts of the state, with a view to highlighting all the investment potentials identified in each of the Local Government Areas of the State for local investors to invest in before other investors are invited and accommodated into the projects.

c) The Ministry has, within the period under review, ensured that all properties belonging to Kano State that are about to "disappear" in Abuja, Kaduna and Lagos are recovered and utilized by the State Government or sold for the proceeds to be used in executing other important projects.

d) The Ministry has embarked on the construction of low-cost two-bedroom houses at a price below N3million per unit with a view to narrowing the Housing deficit in the state. This project is being coordinated by KSIP.

e) The Ministry has spearheaded the process of obtaining the N2billion Central Bank of Nigeria (CBN) Micro, Small and Medium Scale Enterprises (MSMEs) loan for distribution to target beneficiaries at no-interest rate. The amount was obtained and managed through the active participation of Kano State Microfinance Bank Agency (KASMA), which serves as the SPV of the project.

f) More than 20, 000 beneficiaries accessed the CBN MSMEs loan across the 44 LGAs of the state, with the active involvement of 45 Microfinance Banks (MFBs) that are being supervised by KASMA in the state.

g) Items $\mathrm{d}$, e and $\mathrm{f}$ are measures taken to ensure financial inclusion and to narrow the gap between the rich and the poor in the state. Again, these measures are part of the Ganduje's Administration effort to re-invent the lost Middle Income Class, which is the engine of sustainable economic growth and development anywhere in the world.

h) The revival of Dala Building Society (DBS) PLC is another challenge the Ministry is accomplishing with a view to ensuring that a Primary Mortgage Bank/Institution (PMI) is present in Kano State to take care of all the government policy matters on provision of housing and other mortgage-related projects, like Family Home Funds of the Federal Government.

i) DBS PLC has the potentials to bring about strong financial inclusion, and even economic inclusion in a very short while, especially as many investors across the country have approached the Interim Management Committee (IMC) of the Bank for partnership in the provision of mass-low-cost houses across the 44 LGAs in the state.

j) The Ministry has understood that poor Domestic Direct Investment (DDI) and poor Foreign Direct Investment (FDI) are the main problems hampering the fast industrialization and sustainable growth and development of the state. In order to deal with this set back to the state economy, the Ministry embarked on a Town Hall Meetings (THM) scheme across the 44 LGAs to, among other objectives, mobilize the good people of the state, from the grassroots, to accept the need for them to invest the little savings they have into some viable ventures in their localities.

\subsection{Wealth Creation and Management}

The Ministry has made efforts over the last 28 months to create wealth for the state and to ensure effective management of the wealth in a number of ways, which are summarized below:

a) Measures taken to ensure the conversion of the state economy from Oil-Revenue-based to productivity-based or tax-based has put the state on the path to wealth creation, as everybody is mindful of what the government is actually doing with the tax-revenue being generated. Tax or levy payers (corporate organizations or individuals) are stakeholders that care about what government is doing with their contributed money.

b) Working towards the growth of Micro to small, small to medium and medium to large scale industries/businesses for job creation and revenue generation in the state is one of the key efforts of the Ministry. This ensures re-invention of the Middle Income Class in an economy, and ultimately ensures wealth creation.

c) Taking measures that ensure economic and financial inclusiveness from the grassroots level upwards so that productivity is optimized for fast economic growth and development.

d) Throughout the 28 months under review, the Ministry ensures that salaries of both the state civil servants and local government workers have never been unreasonably delayed, month-in, month-out. As salaries and pensions are paid, markets and industries are patronized (lubricated) for them to continue to be productive and this ensures employment generation and job sustenance in the state.

e) Interest-free vehicle loan scheme, which had been truncated for about 5 years now, has been relaunched through the strategic concern of the Ministry by first separating deductions from previous Vehicle Loan beneficiaries into the Vehicle Loan Account to generate about N120million. This was used to grant the loan to 650 applicants. The joy of 
this action encouraged the government to "pomp" in N450million, from its Strategic Investment Account, to add to the N90 million in the Vehicle loan account for another 2600 applicants to be granted the loan at a value of N540million. This was done in a grand ceremony performed by His Excellency, the Governor.

f) Ensuring that the housing deficit in the state is filled, through low-cost mass housing project being executed under the auspices of KSIP, while providing employment and other economic benefits in the process. It is estimated more than $40 \%$ of the total cost of the project is labor-related cost!

g) Mobilizing the people of the state from the grassroots level for investment in various medium term and long term business ventures, with a view to encouraging large scale investors (especially FDIs) to have confidence in the investment opportunities of the state for them to invest their investable funds. This would move the state economy forwards on sustainable basis.

h) Through the established culture of prudence, transparency and accountability instituted by the Ministry within the 28 months period, as per the Expenditure Management highlights, the state government is able to attract support from bilateral and multi-lateral organizations in the form of Aids, Grants and other interventions. These facilitate wealth creation in the state.

i) The Ministry drives the process of enacting Fiscal Responsibility Law (FRL), Public Procurement Law (PPL), Bond Law (BL), Public Private Partnership Law (PPPL) and Public Finance Management Law (PFML), all with a view to attracting investments, aids, grants and low-interest loans to boost efforts at wealth creation in the state. It is hoped that the new leadership of the Ministry will finish up the process.

j) The Ministry's ability to attain effective Debt Management, with regular reports to relevant stakeholders, is attractive to DD Investors, FD Investors and subscribers to any debt instrument that would be issued by the state government to mobilize funds from the capital market for financing developmental projects.

k) The Ministry's efforts at following up various intervention funds from the World Bank, French Development Agency, Islamic Development Bank, Federal Ministry of Finance and the country's development partners, etc pave ways for the execution of many developmental projects that amount to wealth creation, in many ways.

\section{Key Achievement Recorded}

Arguably, the most important achievement recorded by the Ministry within the 28 months under review is its ability to become united and to ensure the spirit of togetherness in whatever the functionaries do, at any given time. It is the unity, synergetic and spirited togetherness in the functionaries' working relationship that ensures the successes recorded on all the five (5) key responsibilities of the Ministry. At the time of assumption of office by the author, the Ministry was found to be a "divided house", based on selfish interests and mistrust among key functionaries then.

It is hoped that all the efforts made to ensure sincere and honest working relationship and togetherness in running the affairs of the Ministry in a transparent and accountable manner will continue, so that more success stories could be recorded by the Ministry.

\section{Testimonial From Well Wishers}

In response to the online publication of the preliminary version of the account of stewardship, hundreds of commentators have expressed their views and well wishes. Below is a selected sample of those highly respected and concerned commentaries on the published account:

1). Congratulations a Gama lafiya. Allah ya zaba maka abin da ya fi alkhairi ya ba da ladan bautawa al'umma da aka yi. (Congratulations for a successful service to the state. May Allah choose for you a better responsibility, and may He reward you for a service well done to humanity).

Mun gode (We are grateful).

Muhammad Sunusi II (MSII), HRH, the Emir of Kano

2). Masha Allah,

This is surely an excellent account. May Allah reward you abundantly, and may your effort provide the key guidance for all in governance.

We're immensely proud of your achievements and diligence.

Professor A.I. Tanko, PhD, FRGS, Deputy Vice Chancellor (Administration) and Former Dean, Faculty of Earth \& Environmental Sciences, Bayero University, PMB 3011, Kano, Nigeria 


\section{3). Dear Prof.,}

Congratulations for these great achievements, knowing who you are and your capacity it is not a surprise. This kind of feedback on performance is a great indication that this country has responsible and accountable human resources for development. It is very exemplary and I believe greater things are ahead. Keep up the great sense of accountability and performance.

\section{Mr. Emmanuel Musa, Consultant and Businessman based in Abuja, Nigeria}

4) My dear Prof Salam alaikum,

I received and read the account of your stewardship as the Hon Com. for Finance, Kano State with delight. I said with delight because I was in no doubt that you had the capacity to do much more given the leeway to operate as you deemed fit. But it is a political office and in such offices professionalism and single mindedness are least required. Despite all the known limitations of the office you were able to do exceedingly well as expected by all those who know your hard working culture. Congratulations.

Now that you are out of government and back to your familiar environment, May Allah strengthen you and bless your future endeavours.

Once again, please accept my sincere congratulations for coming out of government clean and unblemished.

\section{Aminu Usman PhD, Senior Lecturer in Economics, Kaduna State University}

5) Somehow, the communication on your submission on the above subject shows up in my e-mail. First, let me express my surprise that you decide not to complete the four-year term. However, knowing very well that you are a true and dedicated academician to the core, the 28 months of quasi-political service must have made you feel like fish out of water. I am sure you have solid academic reasons for taking that decision which some Nigerians may see as strange. I am sure you must have performed your duty with the same dedication, transparency, honesty and hard work with which you pursue your academic career. I expect that your sense of accountability and openness must have stepped on some political toes in a country where such academic qualities do not mix well with political sagacity. Welcome back to where you belong and I wish you all the best and continued guidance by the Almighty. Thank you for your continued favourable regard for my person that makes you include me in the distribution of the communication in focus. Keep the flag flying!

Emmanuel A Olofin, Professor Emeritus in Geography, Bayero University, Kano, Nigeria

6) My dear Prof.,

You have done brilliantly, and demonstrated that you are a worthy son of your State. This has also been attested to by many. I am personally impressed.

As you step out, Allah will open other good doors unto you. Amin.

Professor Teju Somorin, FCTI, Professor of Taxation, BA (Hons), MTAX, MPA, FCIPA, FIoE, FIMC, CNA, MNIM, Doctor of Letters (D.litt), PhD Taxation, Doctoral Fellow, AClarb (UK), Member, Institute of Fiscal Studies (UK), Immediate Past President, Chartered Institute of Taxation of Nigeria (CITN);

\section{Retired Coordinating Director, FIRS}

7) Dear Kabiru Dandago,

Thank you for sharing your 49 modest achievements with me. One of the problems of our politics is lack of continuity and consistency. This has to a greater extent made us unprogressive.

I hope your successor will look at these successes critically and build upon them. All of us should learn from His Excellency the Governor on continuing on the projects he found worthy to complete during his tenure. So much public fund has been invested to create good projects, why abandoning them? Why starting another one that you too cannot complete. By completing a worthy project you have added more value to the people who benefit from it.

I congratulate you for being bold to tell us what you achieved during your 28 months in office. I wish all of us would be bold enough to say what we did and what we did not do and leave the rest for posterity to judge us.

I believe more than I believe now, that no condition is permanent. The world is stage every one of us have our own entrances and exits. As a Teacher, I hope your exposure in the last position would be useful to your students.

My regard and best wishes

Bala Inuwa FIMC, Managing Director, Kano Agricultural Supply Company (KASCO) Ltd, Kano, Nigeria 


\section{8) Dear Honourable Prof.,}

I have gone through your stewardship account as the Kano State Commissioner of Finance. It is on record that you have left a legacy for your immediate and subsequent successors. I know it is difficult for an honest person to work with our politicians.

The numerous Town Hall Meetings held by you with various stakeholders showed your zeal and commitment to improving the state of affairs of Kano State.

It is worth noting that you initiated the process of remitting VAT and WHT deductions to relevant tax authorities with a view proper accountability and providing acknowledgement to organizations/individuals from whom such deductions were made. Hitherto, such deductions were never acknowledged .I hope your successor will continue this notable achievement.

A vacuum has been created by your exit as far as ICAN is concerned. I am, however, happy that you bowed out honourably.

Thank you for your personal attention to me while in office. I am very grateful.

Whatever circumstances that led to your exit, be encouraged that you made a mark in Kano State Ministry of Finance during your short stay as the Finance Commissioner. It is my prayer that the Almighty God open a better way for you.

Best regards.

\section{Mike Akpojeherhe Ukueje, FCA, Managing Partner, Mike Ukueje \& Co (Chartered Accountants), Kano, Nigeria}

\section{9) Dear Professor Dandago,}

Thank you for sharing your amazing stories of impact with me. I feel honoured. I am not surprised at your great sense of service and accountability.

Prof, what I am seeing are not modest achievements. They are truly transformational milestones. You have done what every great leader do. You have not only achieved greatly through your unique blend of personal humility and professional will, you have laid a solid foundation for the future greatness of Kano state. More instructively, you have set your successor up for success and for this singular achievement, posterity will never forget you.

Thank you for making us proud. Your colleagues at BUK - especially those of us the younger ones who are always inspired by your professional excellence, your work ethics, your credibility and your great attitude towards all people - are particularly happy that you have lived above aboard and made a clear statement that not all good people in government get swallowed up by culture of inefficiency, ineptitude, recklessness and corruption. This has huge impact on our psyche as it gives us a positive and empowering reference to aspire to. For these, Allah will reward you in his special way.

As you take a bow out of the ministry, I pray that Allah will continue to protect you and your family. May He direct your footsteps and make it easy for you to achieve much greater things in bigger assignments that will be coming your way very soon.

My wife and I will like to come home and welcome you. Kindly let me know when it is convenient.

Thank you once more sir for the honour. Regards to the family.

Truly yours,

Adams Adeiza, PhD., (Mandela Washington Fellow), Department of Business Administration, Bayero University, Kano, Nigeria

10) My dear Prof Dr Kabiru,

Thank you for sharing your stewardship as Commissioner, Ministry of Finance, Kano State. I am indeed grateful to be opportune to go through the note.

Yes, it is right to document your stewardship during the 28 months as Captain in the Finance Ministry. However, for your followers and lovers, we know you as a performer par excellence, and for the other group that does not share your thoughts and aspirations, it is a sheer waste of time. Posterity will judge your commitment, love, passion for excellence, dedication, and avowed loyalty to the government and the people of Kano State.

As you move on in the next endeavours, I pray Allah (SWT) to grant and bless you with more wisdom, knowledge and understanding. 
Thank you for your service to your motherland.

Oluwatoyin Popoola, PhD, FCTI, FCA, CFA, RPA, Visiting Lecturer, College of Accountancy, Universiti Utara Malaysia (UUM)

11) Honourable,

Thank you so very much, first of all, for taking the time to give a detailed account of your stewardship as Finance Commissioner in the current KNSG administration. It will be great if others who held public offices emulate you and give such detailed account of what they did (or failed to do) while in office. Second, I must thank you for the impressive achievements you have recorded during your tenure in office.....like we keep saying, great things happen when competent people are given the chance to serve. On behalf of all of us who served with you at the KRTT (Kano Renaissance Think Tank), we thank you for the amazing public service. You helped pushed many of our (KRTT) recommendations to the government, and we hope they will continue to actualize them even while you are no longer in office. You served with honour, dignity, simplicity, prudence, accountability and humility. During your tenure, you built an image and laudable reputation for honesty, incorruptibility and respect for all. You rose above partisanship (even when there was huge temptation to do so)....and remained laser-focused on your work. You reached out to anyone and everyone (regardless of politics or any other consideration) who can help you achieve results for the people of the Great State of Kano. You helped to unify people and broker peace (in at least one hugely tumultuous moment). These are rare qualities.....and many in public service would do well to dutifully emulate them. You made us proud.....and may we have a lot more of your type in public service.

Abba Gumel, PhD, FAS, FAAS, FCBCS (ASU-Santa Fe Inst.), Professor of Mathematics \& C. Castillo-Chavez Professor of Mathematical Biology, Arizona State University, Tempe, Arizona, 85287-1804, USA

12) Alhamdulillah Prof.,

I am happy for you for the great milestones achieved as well as the transformation and the value added you brought to bear in the Ministry. This is a clear difference between a technocrat and a politician. Your landmark achievements and the changes you brought would remain legacies you left behind and point of reference now and in the future.

May Allah (S.W.A) continue to increase you in knowledge, wisdom, and good health, and may He also continue to protect and guide you through out your endeavours ameen thumma ameen. Regards.

Murtala Zakari, ACA, ACTI, ACSA (U.S.A), Banker and Chartered Accountant, Kaduna, Nigeria

13) Prof. Kabir Isa Dandago,

Good day Sir,

We are proud of you always and I am sure Kano State is also proud of you. Kano State and Nigeria are highly lucky to have you.

When I first met you at the Kaduna State University, International conference of Management and Social Sciences 2013 where I was a co-presenter of a research work we conducted on Workman Compensation Act and again last year as Lead Consultant of Bigways Consult Limited, I knew it that you will one day becomes the Governor of Kano state INSH ALLAH.

WE AT BIGWAYS CONSULT LIMITED are proud of your steward at the ministry of Finance, Kano State, we are praying for you and we are always proud of you sir.

Once again we say congratulation for such a wonderful stewardship you have rendered to Kano State and Nigeria in general.

Kekere Solomon Omeiza Esq., BIGWAYS CONSULT LIMITED, Kaduna, Nigeria

14) Dear Kabiru Dandago,

Thank you very much for sending me a copy of your stewardship statement. This raises some very interesting issues and is certainly worthy of congratulation of your achievements.

It seems to me that if it could be developed it would provide a very interesting article for the International Journal of Governmental Financial Management: http://www.icgfm.org/publications/journal/

I had a few questions about your report:

1. To what extent did you consider the Federal "Fiscal Sustainability Plan" a useful document in terms of priorities for reform of the state's finances? 
2.To what extent did you consider that the donors were a useful source of funds and technical advice? How do you think that the relationship with the donors could be improved? (this is a core interest for the research bid from de Montfort University)

3.What are the main IGR streams which you were able to grow for the state? Where did most IGR growth occur at the State level?

4. What are the key areas for IGR growth in local governments?

5. Is the quarterly report on expenditure now made public as a budget out-turn report as required by the Fiscal Sustainability Plan?

6. Do you know which software the state is using for its SIFMIS (Oracle, SAP etc)? Did you consider Mold Computers from Kaduna which appears to be a very cost effective solution using Sage?

7. Do you know the cost of the valuation of the State's fixed assets? This appears to be an area where savings could be made.

I look forward to receiving any answers to the above questions that you feel able to answer.

I also look forward to further cooperation.

I will be returning to Abuja again on 8th November.

All best wishes

Andy Wynne, 8 Vincent Close, Leicester LE3 6ED, Telephone: 0116 2858794, Mobile Britain: +44 7885886575

15) Kabiru,

I really do not have the time to digest everything that you have done to reflect your efforts as you have written. I however know that you never fell short in carrying out your duties diligently and without fear or favour.

The very fact that the news reads as that you have been sacked is what disturbs me a lot in spite of all your good works.

Notwithstanding of the above concern and understanding that these are all made under a government that you support very much, it did come as a surprise to me. That is the least I expected to happen to you. I really thought all will end well with you with this government irrespective of the challenges you faced.

Please bear in mind that you can do far more and in fact much better as an academician and educationist.

I am not so worried about your next step but whatever you do, please ride with wisdom and be cautious. I hope you will never again take up any post with the political parties in the future.

Take care please and be happy.

Regards

Rebecca Jane Thomas, Educationist and Social Worker, Kuala Lumpur, Malaysia, 016-2207091

16) My Dear Prof.,

We thank the Almighty Allah for a very successful tenure. I trust your performance always and the Almighty Allah will continue to give you wisdom to excel. Well done.

Alhaji Razak Jayeola, Vice President, Institute of Chartered Accountants of Nigeria (ICAN)

17) That is great. Allah yasa a mizani amin (may Allah count it as part of your good deed in the hereafter). What you did is exactly in line with the saying "account for your deeds before you will be accounted for in the sight of Allah"

Mrs. Safiyya Abubakar Abba, Lecturer, Sa'adatu Rimi College of education, Kumbotso, Kano State, Nigeria

18) Prof.,

Good day and congratulations for a successful tenure as the Honourable Commissioner for Finance.

I want to personally appreciate your comradeship and team spirit which are playing out at all times.

As you move higher, we your associates are moving with you.

Once again, Congratulations.

Prof I. R. Akintoye PhD, FCA, FCTI, FNIM, Professor of Accounting, Babcock University, Ogun State, Nigeria 
19) Dear High Ranking Professor,

I congratulate you and thank God for the great achievements. It is a plus to our great Institute. Higher calling to a greater service await you. Extend my greetings to your amiable wife and children.

Prof. R. O. Salawu PhD, FCA, Department of Management and Accounting, Obafemi Awolowo University, Ile-Ife, Nigeria

20) I have gone through but as i like to be frank. I hope to give you my analysis of the document soon. Meanwhile, I thank you for being an exemplary Nigerian. I need to thank you because having somebody of your status who believes in stewardship is rare in our Country. I also follow you on how much you cherish transparency and accountability. Since my over a decade association with you, i noticed that in whatever you are doing, you believe you owe someone an explanation. Most of all you still have time to show kindness and support to whoever comes across you. You are as simple as simplicity.

Today the day of congregation, I thank GOD for your successful tenure. I pray that better things shall follow. I appeal to GOD to use people like you to turn around Nigeria for better. I beg ALMIGHTY GOD that you do not lack good health, prosperity and long life (amen). Best wishes all the way.

Shakirat Peju Babatunde FCA, Ranking ICAN Council Member \& Director, Ministry of Finance, Lagos State, Nigeria

21) Prof.,

Thank you for sharing this success story, congratulations for a successful tenure.

Prof. Ismaila Muhammad Zango, Dean Students Affairs, Bayero University, Kano, Nigeria

22) Hi Prof.,

Congratulations on these remarkable achievements, in just 28 months.

You need to have a good holiday now before moving on.

Regards.

Dr Muhammad Surajo Sanusi, B.Sc. (Hons) (BUK), M.Sc. (ABU), MBA (BUK),Ph.D. (UK), CNA (ANAN), ACTI (CITN), ACCA (UK), ACA (ICAN), Deputy Programme Leader: M.Sc. Accounting \& Finance, Birmingham City University, United Kingdom

23) Congratulations to you my Prof.,

You have always been a great achiever. Kudos!

Chinwe Regina Okoyeuzu, PhD, Lecture, Department of Banking and Finance, University of Nigeria, Nsukka

24) Thanks a lot Prof for your mail highlighting your achievements and legacy during your tenure as Kano State Commissioner for Finance.

For many of us who have related with you in one way or another, we expected nothing less from you. You have succeeded in making us proud. May Allah reward you for your efforts.

Prof. Aminu S. Mikailu, Former Vice Chancellor of 3 Universities: Usman Danfodio University, Sokoto, Kaduna State University and Nassarawa State University, Keffi all in Nigeria

25) Dear Prof.,

Thanks for writing about your contributions. I hope you will have time in the future to write a book. I did not realize you left the cabinet until I saw this. I hope you will take time to rest.

All the best.

Amina Ado Kurawa MSc, MBA, ACCA, ACA, Consultant and Philanthropist, Abuja, Nigeria

26) Congratulations for a worthwhile tenure full of achievements. May Almighty Allah reward you and secure your future.

Umar Saidu Tudunwada, Chairman/Editor in Chief, Amara Creative Studios, Suite 187, SKY Memorial Complex, Zoo Road, Kano, Nigeria 


\section{Responses to Andy Wynne's Questions}

5.1 To What Extent Did You Consider the Federal "Fiscal Sustainability Plan"- A Useful Document in Terms of Priorities for Reform of the State'S Finances?

The Federal government's Fiscal Sustainability Plan (FPA) and its 22-point agenda should be accepted as the best attempt at encouraging (forcing) states government to demonstrate high degree of prudence, transparency and accountability in public financial management. The Plan was securitized to Budget Support Facility (BSF) of around N14.5billion granted to each of the 36 states government of the Federation. The condition was that all the states government would be very faithful to the implementation of the Plan.

The FSP document carries priority areas like the need to exercise transparency and accountability (through timely reporting, using IPSAS Accrual basis Accounting), avoidance of waste in public financial management (through efficient capital and recurrent expenditures), effective debt management (for "profitable" utilization of domestic and foreign loans), aggressive internal revenue generation and utilization and many other priority areas necessary for ensuring sustainable economic development.

FSP is a very strategic document for reforming the states' finances, and putting them on the path for economic recovery growth, and pushing them towards sustainable economic development. But it appears as if efforts at enforcing the implementation of the 22-point agenda are weak!

5.2 To What Extent Did You Consider That the Donors Were a Useful Source of Funds and Technical Advice? How Do You Think That the Relationship With the Donors Could Be Improved? (This Is a Core Interest for the Research Bid From de-Montfort University)

Donors or development partners, as they called in Nigeria, are very useful sources of revenue to Kano State government. They serve as very useful technical advisers to the state government in all the sectors of the state economy where they are committed to assist.

Their participations and supports to various projects meant for the state government to take care of in the areas of health, education, environmental management, water resources, agriculture, etc have been very impressive. The government had cause to organize Donor/Development partners' joint conference and exhibition to showcase the contributions they make in solving many humanitarian problems in the state and to appreciate them with esteemed regards of the Governor and the whole government.

The Ministry has been calling for the quantification of all the social works they do in monetary terms so that the state government captures the value of all the monetary and non-monetary donations or social works provided by the Development partners as they contribute towards the development of various sectors of the state economy. The value arrived at has to be accounted for as part of the monthly or annually determined Internally Generated Revenue (IGR) of the state. The value should not go unaccounted for as part of the IGR effort of the state government and as part of the audited financial statements of the state.

Relationship with the development partners could be improved upon through transparent utilization of their donations and through demonstrating full accountability of the results obtained, showing and appreciating essentially the impact made by their participation to the wellbeing of the people.

5.3 What Are the Main IGR Streams Which You Were Able to Grow for the State? Where Did Most IGR Growth Occur at the State Level?

When the Ganduje Administration came on board, we realized that the main source of IGR was PAYE (Pay As You Earn) and Fees on Tenders. Other important sources of IGR were either not being effectively utilized to the optimum level or they were suffering from high degree of leakages. With His Excellency the Governor's political will on the IGR derive, we became determined to grow other revenue streams and make non-productive streams become active.

Using our expertise and reaped ideas from Technical Advisers, we were able to identify eight streams for massive IGR enhancement, as follows:
a. Land Use Charges
b. Telecommunication Charges
c. MDAs Revenue
d. Road Taxes/Levies
e. Recovery (Back duty Investigation) 


\section{f. Informal Sector (Presumptive) Tax}

g. Unearned Income and sell of government assets

h. PAYE

Efforts have been made, including enactment of Land Use Charge (LUC) Law 2016, to ensure that LUC contributes at least $40 \%$ of the state total IGR collection, just like it happens in Lagos state. We have not reached there yet, but tremendous improvement has been made as the necessary structures have been put in place to achieve that target. Telecommunication charges (on Right of Way, Telecommunication Masks, etc) that were not adding much value to the state government's IGR are now parts of the main sources of revenue to the state, in view of the various reform/revolutionary actions taken.

With the enactment of the MDAs Revenue Harmonization Law 2016, a lot of measures have been taken to ensure that all revenues from MDAs go to the Single Revenue Account (SRA) to be accounted for on monthly basis by the reporting Bank. The roles of the Collecting Banks and Lead Banks have also been made very clear, likewise the limit of exemption given to Authorized MDAs on re-crediting of their accounts with revenue generated by them, subject to the provisions of the Appropriation Law. Efforts at Recovery have been contributing high amount of revenue since the commencement of the Ganduje Administration, in view of the aggressive follow up we have mounted on all tax-debtors that have not settled their debts to the state over the past 3-7 years, many of whom are Agencies of the FGN!

Road Taxes/Levies and Presumptive Tax are two streams that are too problematic, even as they have the largest number of prospective tax papers who are outside the tax net. Even though the amount collectable from each one of them is not big enough, the aggregation of the collection would be large enough to tremendously enhance the IGR of the state. Besides, we have the keen belief that the contribution of the target taxpayers from the two streams is what would make them to assume effective ownership of the government and demand transparency and accountability on the way government expenditures are incurred. With commitment and dedication from the Revenue Agency (KIRS) we are hopeful that the two streams would compete favorably with the streams that are not leading the pact!

\subsection{What Are the Key Areas for IGR Growth in Local Governments?}

At the local government level in Kano State, the key areas for IGR growth are motor parks, market stalls, outdoor advertising, and some elements of road levies/charges. These are areas upon which we have worked assiduously to guide and assist all the 44 LGCs in the state to make effective use of in growing their IGR.

Constitutionally, about 17 sources of revenue have been identified for local government councils to utilize to generate revenue but, due to political and social considerations, local government administrators are finding it difficult to make use of them to grow their IGR. Most of the LG administrators prefer to allow these sources of revenue to leak out to the pockets of their campaigners as a way of compensating them!

Efforts have been made to carry the 44 LGCs a long through the avenue of Joint Tax Committee, which is constitutional. Representatives of KIRS, leadership of all the 44 LGCs and relevant FGN Agencies were constituted into the Committee, with clear terms of Reference and mandate to ensure that all sources of revenue that require joint efforts of the SG and LG are effective utilized to generate maximum revenue and to share same equitably. The state government is still struggling to ensure that the Committee's mandates are actualized with a view to growing up the IGR of the two tiers of government.

5.5 Is the Quarterly Report on Expenditure Now Made Public as a Budget Out-Turn Report as Required by the Fiscal Sustainability Plan?

We were able to ensure that transparency exists on the quarterly budget out-turn report in respect of both revenue and expenditure profiles of the state. This exercise, which is under the jurisdiction of the Ministry of Planning and Budget, is being conducted in the presence of all stakeholder-MDAs and civil society groups in the state.

As part of our effort to ensure the state government compliance with the requirements of the Fiscal Sustainability Plan, we had concluded arrangements to ensure that these types of reports are posted to all the websites belonging to all the government's MDAs, so that as you access any information about the KNSG, you can access also its Approved Budget and the numerous reports that could be produced from its implementation. 
5.6 Do You Know Which Software the State Is Using for Its SIFMIS (Oracle, SAP etc.)? Did You Consider Mold Computers From Kaduna Which Appears to Be a Very Cost Effective Solution Using Sage?

As at the time the author left office, the State Integrated Financial Management Information System (SIFMIS), which is being developed by consultants commissioned by SLOGOR, has not yet been concluded for report to be made available to the government. The issue of the software in use is not finalized since the system is still work in progress (WIP).

I am not aware of the Mold Computers in reference!

5.7 Do You Know the Cost of the Valuation of the State's Fixed Assets? This Appears to Be an Area Where Savings Could Be Made

As the KNSG made efforts towards developing fixed assets register and determine the value of all its fixed assets, in line with the requirements of International Public Sector Accounting Standards (IPSAS) Accrual basis, the Ministry of Finance had contacted some professional accountants for quotation on what should be paid to them to do full valuation of all fixed assets. The firms' responsibilities include determining appropriate depreciation methods and rates for all the categories of fixed assets owned by the state government.

None of the three Accounting firms contacted gave a quotation below M70million to capture all the fixed assets of the state government in appropriate register, determine their fair value, ascertain appropriate depreciation methods and proposed relevant depreciation expense rates. This is what would facilitate determination of net book value for all the fixed assets at the end of every year until the assets are fully depreciated for replacement to be made.

\section{Conclusion}

This paper captures highlights of 49 main achievements recorded by Ministry of Finance, Kano State, Nigeria during the 28 months tenure of the author as Commissioner of Finance, Kano State, Nigeria. The exposed achievements attracted commentaries from concerned individuals on the degree of transparency and accountability in public financial management demonstrated by the Ministry during the period under review and level of determination and commitment demonstrated to fulfil the promise made during the swearing-in ceremonies of the author as the Commissioner of the Ministry.

One of the commentators raised seven important questions on the account of stewardship to which responses have been attempted, hoping that the section adds value to the effort at demonstrating prudence, transparency and accountability.

It is hereby recommended that public financial management scholars and public sector accountants should consider various issues raised in the paper for further deep-rooted research, with a view to finding solutions to the problems of weak level of prudence, transparency and accountability in public financial management in the three tiers of government in Nigeria and other developing countries.

\section{References}

Apampa, S., \& Oni, T. (2009). Africa Fiscal Transparency-Nigeria. Fiscal Transparency Research Team in Nigeria.

Babatunde, S. A. (2013). Stakeholders' perception on the effectiveness of internal control system on financial accountability in the Nigerian public sector. International Journal of Business and Management Invention, 2(1), 16-33.

Ball, I. (2012). New development: transparency in the public sector. Public Money \& Management, 32(1), 35-40. https://doi.org/10.1080/09540962.2012.643054

Carrington, DeBuse, J., \& Lee, H. (2008). The Theory of Governance \& Accountability. Retrieved December 17, 2013, from http://blogs.law.uiowa.edu/ebook

Curristine, T., Lonti, Z., \& Joumard, I. (2007). Improving Public Sector Efficiency: Challenges and Opportunities. OECD. Journal on Budgeting, 7(1), 1-41. https://doi.org/10.1787/budget-v7-art6-en

Dandago, K. I. (2007). Public Wealth and Accountability in Islam: A Case Study of the Shari'ah Administration of Shekarau in Kano State, Nigeria. Public Fund Digest, the Official Journal of the International Consortium on Governmental Financial Management (ICGFM), 6(1), 1-10.

Dandago, K. I. (2008).The Constitutional Fight Against Corruption in Nigeria: Is It Enough?. Public Funds Digest, the Official Journal of the International Consortium on Governmental Financial Management (ICGFM), 8(1), 
Ebimobowei, A., \& Onuorah A. C. (2012). Accountability and public sector financial management in Nigeria. Arabian Journal of Business and Management Review (OMAN Chapter,) 1(6), 1-17. https://doi.org/10.12816/0002105

Economic Commission for Africa (ECA). (2009). Assessing Public Financial Management and Accountability in the context of Budget Transparency in Africa. Retrieved from http://www.uneca.org/eca/publications/dpmd/budget_transparency.pdf

Feng, J., Hao, R., Li, Y., \& Zhang, K. (2012). The Effect of Leadership Transition on Government Expenditure: Evidence from China. Annals of Economics and Finance, 13(1), 91-112.

Guthrie, J., Olson, O., \& Humphrey, C. (1999). Debating developments in New Public Financial Management: the limits of global theorizing and some new ways forward. Financial Accountability and Management, 15(3/4), 209-228. https://doi.org/10.1111/1468-0408.00082

Kitunzi, A. (2003). Fiscal Transparency for Good Governance.

Kopits, G. \& Craig, J. (1998). Transparency in Government Operations. IMF Occasional Paper 158. https://doi.org/10.5089/9781557756978.084

Lalvani, M. (2010). Public Expenditure Management Reform in India via Intergovernmental Transfers. Public Budgeting \& Finance, 98-133. https://doi.org/10.1111/j.1540-5850.2010.00964.x

Lambert, R., Leuz, C., \& Verrecchia, R. (2007). Accounting Information, Disclosure, and the Cost of Capital. Journal of Accounting Research, 45(2007), 385-420. https://doi.org/10.1111/j.1475-679X.2007.00238.X

Leruth, L., \& Paul, E. (2007). A Principal-Agent Theory Approach to Public Expenditure Management Systems in Developing Countries. OECD Journal on Budgeting, 7(3), 103-131.

Maesschalck, J. (2004). The Impact of New Public Management Reforms on Public Servants'Ethics: Towards a Theory, Public Administration, 82(2), 465-489. https://doi.org/10.1111/j.0033-3298.2004.00403.x

Meier, K. J., \& O'Toole, L. J. (2002). Public Management and Organizational Performance: The Impact of Managerial Quality. Journal of Policy Analysis and Management, 21(4), 629-43. https://doi.org/10.1002/pam.10078

Slukhai, S. (2011). Monitoring and evaluation as tools for enhancing public expenditure management in Ukraine. Financial Theory and Practice, 35(2), 217-239.

Vukicevic, A., \& Bartholomew, R. (2008). Public Expenditure Management Peer Assisted Learning (PEMPAL) Initiative in Europe and Central Asia. International Journal of Governmental Financial Management, 15-23. 